\title{
Identifikasi dan Predileksi Ektoparasit Kepiting Bakau (Scylla spp.) dari Ekosistem Mangrove Taman Hutan Raya (TAHURA) Ngurah Rai, Bali
}

\author{
Ilham Muttaqin a*, Pande Gde Sasmita Julyantoro a, Alfi Hermawati Waskita Sari a \\ a Program Studi Manajemen Sumberdaya Perairan, Fakultas Kelautan dan Perikanan, Universitas Udayana, Bukit Jimbaran, Bali-Indonesia \\ * Penulis koresponden. Tel.: +62-812-367-591-23 \\ Alamat e-mail: ham.muttaqin@gmail.com
}

Diterima (received) 5 Juli 2018; disetujui (accepted) 13 Agustus 2018

\begin{abstract}
This research aims to know the various types, predilections, prevalence and intensity of ectoparasites on mud crab (Scylla spp.) and water quality condition in Taman Hutan Raya (TAHURA) Ngurah Rai, Bali. This research was conducted in TAHURA mangrove ecosystem which has 219 hectare of research area near to Pemogan village from February to April 2018. The research used descriptive method by using random sampling for collecting data. Mud crabs obtained in this research consisted of 21 individual mud crabs that belong to 3 species, namely Scylla olivacea (11 ind), Scylla serrata (9 ind), and Scylla tranquebarica (1 ind). The observations results found 5 types of ectoparasites namely Zoothamnium sp. (2021 ind), Epistylis sp. (955 ind), Carchesium sp. (7 ind), Vorticella sp. (98 ind), and Octolasmis sp. (201 ind). Organs infected by ectoparasitic are legs (517 ind), swimming legs (476 ind), carapace (740 ind), claws (1348 ind), and gills (201 ind). The highest prevalence rate obtained was Zoothamnium sp. and Epistylis sp. about $95,23 \%$ while the lowest prevalence rate was Carchesium sp. about $4,76 \%$. The highest level of intensity was Zoothamnium sp. about 101,05 ind/crab, while the lowest intensity obtained on Carchesium sp. with 7 ind/crab. The condition of water quality was still considered optimal for mud crab (Scylla spp.) life with average temperature of 29,9 ${ }^{\circ} \mathrm{C}$, dissolved oxygen $6,6 \mathrm{mg} / \mathrm{L}$, salinity $20 \%$, and $\mathrm{pH} 7,39$.
\end{abstract}

Keywords: Scylla; parasites; mangrove; Bali

\begin{abstract}
Abstrak
Penelitian ini bertujuan untuk mengetahui berbagai jenis dan predileksi ektoparasit pada kepiting bakau (Scylla spp.) dan kondisi kualitas air di Taman Hutan Raya (TAHURA) Ngurah Rai, Bali. Penelitian ini dilakukan di ekosistem mangrove TAHURA yang memiliki 219 hektar pada daerah penelitian di dekat Desa Pemogan dari Februari hingga April 2018. Penelitian ini menggunakan metode deskriptif dengan menggunakan random sampling untuk mengumpulkan data. Kepiting bakau yang diperoleh dalam penelitian ini terdiri dari 21 individu kepiting bakau. Hasil pengamatan menemukan 5 jenis ektoparasit yaitu Zoothamnium sp. (2021 ind), Epistylis sp. (955 ind), Carchesium sp. (7 ind), Vorticella sp. (98 ind), dan Octolasmis sp. (201 ind). Organ yang terinfeksi oleh ektoparasit adalah kaki jalan (517 ind), kaki renang (476 ind), karapas (740 ind), capit (1348 ind), dan insang (201 ind). Kondisi kualitas air masih dianggap optimal untuk kehidupan kepiting bakau (Scylla spp.) dengan suhu rata-rata $29,9{ }^{\circ} \mathrm{C}$, oksigen terlarut 6,6 $\mathrm{mg} / \mathrm{L}$, salinitas $20 \%$, dan $\mathrm{pH} 7,39$.
\end{abstract}

Kata Kunci: Scylla; parasit; mangrove; Bali

\section{Pendahuluan}

Kepiting bakau (Scylla spp.) merupakan salah satu komoditas hasil perikanan yang memiliki nilai ekonomis yang cukup tinggi. Potensi kepiting bakau di Indonesia sangat menjanjikan, hal ini dikarenakan Indonesia memiliki wilayah hutan bakau yang luas. Permintaan konsumen akan 
kepiting bakau terus meningkat baik di pasar domestik maupun di pasar internasional, sehingga menjadikan kepiting bakau sebagai komoditas andalan perikanan di Indonesia (Idrus et al., 2016). Menurut KKP (2014), permintaan konsumen terhadap kepiting bakau terus mengalami peningkatan, hal tersebut dapat dibuktikan dengan kepiting bakau yang menjadi ekspor komoditas utama pada tahun 2012-2013 dengan peningkatan volume ekspor sebesar 21,13\% dibandingkan tahun sebelumnya.

Komoditas kepiting bakau di Indonesia banyak diperoleh dari hasil tangkapan di alam, salah satunya yaitu pada ekosistem mangrove yang merupakan habitat utama dari kepiting bakau (Scylla spp.) (Yusuf, 2012). Salah satu ekosistem mangrove yang berpotensi sebagai tempat hidup kepiting bakau di Bali yaitu ekosistem hutan mangrove Taman Hutan Raya (TAHURA) Ngurah Rai, Bali. Kawasan ekosistem Tahura Ngurah Rai, Bali merupakan muara sungai yang menjadi saluran pembuangan dari aktivitas-aktivitas perumahan, restoran, perhotelan, mall, dan pertokoan yang dapat mencemari lingkungan ekosistem mangrove Tahura Ngurah Rai, Bali (Ulfa, 2016). Hal tersebut dapat menyebabkan tertekannya pertumbuhan dan perkembangan ekosistem mangrove di Tahura Ngurah Rai, Bali.

Pencemaran yang terjadi di ekosistem mangrove dapat menurunkan kualitas air sehingga tidak menutup kemungkinan akan menimbulkan penyakit khususnya parasit pada biota-biota yang berada pada ekosistem tersebut seperti kepiting bakau (Rancak, 2014). Penyakit pada kepiting bakau umumnya disebabkan oleh interaksi berbagai faktor yang terjadi pada inangnya termasuk kondisi fisiologis, reproduksi, tingkat perkembangan individu, faktor lingkungan di perairan, dan patogen. Salah satu patogen yang menyebabkan timbulnya penyakit adalah parasit (FAO dan NACA, 2001).

Parasit yang menginfeksi kepiting bakau umumnya berasal dari jenis ektoparasit. Ektoparasit yang biasanya menyerang kepiting bakau antara lain berasal dari kelompok Protozoa yang terdiri dari genus Zoothamnium, Epistylis, Vorticella dan Carchesium serta kelompok Arthropoda yang terdiri dari genus Octolasmis. Perkembangan koloni ektoparasit akan lebih cepat dibandingkan endoparasit seiring dengan kualitas air yang sangat buruk (Yusuf, 2012). Kepiting bakau yang terinfeksi ektoparasit akan mengalami kesulitan untuk bernapas, sulit untuk bergerak, tidak dapat mencari makan, pertumbuhan terhambat dan sulit ganti kulit (Lightner, 1983). Oleh karena itu penelitian tentang identifikasi dan predileksi ektoparasit pada kepiting bakau (Scylla spp.) yang ada di ekosistem mangrove Tahura Ngurah Rai, Bali perlu dilakukan untuk mengetahui kondisi lingkungan habitat kepiting bakau di ekosistem tersebut. Tujuan dari penelitian ini yaitu untuk mengetahui jenis ektoparasit dan predileksi yang menginfeksi kepiting bakau (Scylla spp.) serta mengetahui kondisi kualitas air di Tahura Ngurah Rai, Bali.

\section{Metode Penelitian}

\subsection{Waktu dan Lokasi Penelitian}

Penelitian ektoparasit pada kepiting bakau (Scylla spp.) dilakukan di Ekosistem Mangrove Taman Hutan Raya (TAHURA) Ngurah Rai, Bali dengan area penelitian seluas 219 hektar yang berdekatan dengan Desa Pemogan pada bulan Februari hingga April 2018.

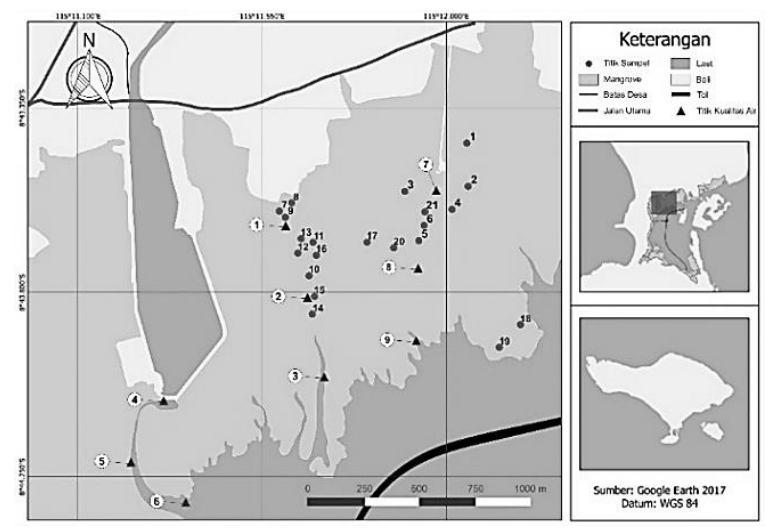

Gambar 1. Peta Penelitian Taman Hutan Raya (TAHURA) Ngurah Rai, Bali

\subsection{Alat dan Bahan}

Alat yang digunakan dalam penelitian ini meliputi Global Position System (Garmin, Etrex 10), Box Styrofoam, pH pen (Lutron, PH-222 Meter), Thermometer (Lutron, PH-222 Meter), Refraktometer (Atago, Master-S/MillM (Cat No 2493)), DO meter (Lutron, DO-5509), Kamera (Canon, EOS 700D), Alat tangkap kepiting (Bubu), Mikroskop (Olympus Corporation, CX21FS1), Laptop (HP Pavilion Gaming Notebook, 15ak035tx), Buku Identifikasi Ektoparasit, Timbangan digital (Shimadzu Corporation Japan, UX-4200 H). Bahan yang digunakan dalam penelitian ini meliputi Aquades, Sampel kepiting 
bakau (Scylla spp.), Sampel kualitas air, $\mathrm{NaCl}$ fisiologis.

\subsection{Pengambilan Data}

Pengambilan data dilakukan dengan menggunakan metode deskriptif, dengan metode pengambilan sampel kepiting bakau dilakukan secara acak (random sampling).

\subsubsection{Pengambilan Sampel Kepiting Bakau}

Pengambilan sampel kepiting bakau pada penelitian ini dilakukan dengan penangkapan langsung menggunakan alat tangkap bubu. Alat tangkap bubu yang digunakan sebanyak 5 unit dengan panjang $28 \mathrm{~cm} \times$ lebar $42 \mathrm{~cm} \times$ tinggi $17 \mathrm{~cm}$. Bubu yang digunakan berbahan dasar jaring PE D6:1 1/4 inci $(3,175 \mathrm{~cm})$.

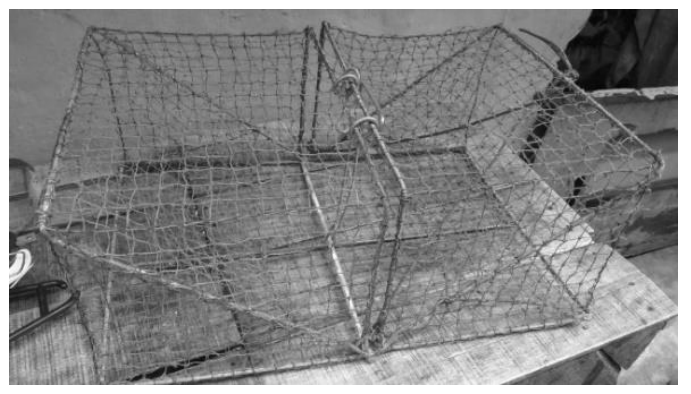

Gambar 2. Alat Tangkap Bubu

Umpan yang digunakan untuk mendapatkan sampel kepiting bakau yaitu daging belut. Penggunaan umpan tersebut dipilih karena memiliki aroma amis yang lebih pekat dibandingkan dengan umpan yang lain. Sesuai dengan pernyataan Sianipar et al. (2017), bahwa penggunaan umpan belut lebih efektif dibandingkan dengan umpan yang lain seperti ikan mujair dan ikan belanak. Lokasi penangkapan sampel dilakukan di area pohon mangrove yang memiliki genangan air dengan beberapa lubang yang terdapat jejak kaki kepiting bakau disekitar lubang tersebut. Penentuan lokasi penangkapan sampel dibantu oleh nelayan untuk mempercepat pengambilan sampel kepiting bakau. Sesuai dengan pernyataan Wijaya (2011), bahwa kepiting bakau hidup di hutan mangrove karena menyediakan suplai makanan yang cukup serta kepiting bakau membuat liang ke dalam lumpur sebagai tempat perlindungan. Setelah lokasi pengambilan sampel kepiting bakau ditentukan, alat tangkap bubu diletakkan di lokasi tersebut pada sore hari saat kondisi perairan surut terendah dan kemudian diambil keesokan harinya pada pagi hari saat kondisi perairan surut terendah.
Sampel kepiting bakau yang telah didapatkan kemudian diikat dan dimasukkan ke dalam box styrofoam yang didalamnya berisi substrat dan air secukupnya yang berasal dari lokasi penangkapan sampel. Sampel kepiting bakau selanjutnya dibawa ke Laboratorium Perikanan Fakultas Kelautan dan Perikanan Universitas Udayana untuk dilakukan pemeriksaan ektoparasit. Penangkapan kepiting bakau dilakukan hingga target jumlah tangkapan terpenuhi yaitu sebanyak 30 kepiting. Sampel kepiting yang diamati adalah kepiting yang masih dalam keadaan hidup, jika sampel kepiting bakau mengalami proses moulting maka sampel kepiting tersebut tidak diambil. Kepiting bakau yang ditemukan kemudian diidentifikasi berdasarkan buku "Kepiting suku Portunidae (Decapoda: Brachyura) dari perairan Indonesia" karangan Pratiwi dan Widyastuti tahun 2013.

\subsubsection{Identifikasi Ektoparasit}

Bagian tubuh kepiting yang diamati untuk pemeriksaan ektoparasit antara lain pada karapas, kaki jalan, kaki renang, capit, dan insang. Kepiting bakau yang diamati sebelumnya dilakukan pengerokan pada mucus dan insang lalu diletakkan pada object glass, ditambahkan dengan $\mathrm{NaCl}$ fisiologis dan selanjutnya ditutup dengan cover glass. Kemudian sampel diamati dengan menggunakan mikroskop dengan pembesaran 40x dan 100x. Hasil pengamatan parasit yang ditemukan dicatat, dihitung jumlahnya dan didokumentasikan. Ektoparasit yang ditemukan kemudian diidentifikasi berdasarkan buku Kabata (1985), Moller dan Anders (1986) dan Mcdermott et al. (2010).

\subsubsection{Parameter Kualitas Air}

Pengukuran parameter kualitas air dilakukan pada titik-titik lokasi yang telah ditentukan yaitu sebanyak 9 titik di sekitar area pengambilan sampel kepiting bakau untuk menggambarkan kondisi kualitas air di lingkungan tersebut (Gambar 1). Parameter kualitas air yang diukur meliputi suhu, pH, Dissolved Oxygen (DO), dan salinitas yang diukur dengan pengambilan sampel sebanyak 3 kali dan dilakukan pencatatan data untuk mendapatkan hasil rata-rata setiap parameter kualitas air. Pengukuran suhu, $\mathrm{pH}$, Dissolved Oxygen (DO), dan salinitas dilakukan secara in situ. 


\subsection{Analisis Data}

\subsubsection{Ektoparasit dan Predileksi}

Data penelitian jenis ektoparasit yang telah diperoleh kemudian diamati dan diidentifikasi berdasarkan buku identifikasi. Data jenis ektoparasit dan predileksi yang telah didapatkan akan disajikan dalam bentuk deskriptif untuk menggambarkan jenis ektoparasit dan predileksi yang menginfeksi kepiting bakau (Scylla spp.) di ekosistem mangrove TAHURA Ngurah Rai, Bali.

\subsubsection{Kualitas Air}

Data kualitas air seperti suhu, DO, pH, dan salinitas diukur dengan cara in situ. Hasil datanya kemudian disajikan dalam bentuk tabel. Dan hasil ini dibahas secara deskriptif untuk menggambarkan kondisi kualitas perairan yang ada di ekosistem mangrove Taman Hutan Raya (TAHURA) Ngurah Rai, Bali

\section{Hasil}

3.1 Jenis ektoparasit dan predileksi yang menginfeksi kepiting bakau (Scylla spp.) di TAHURA Ngurah Rai, Bali

Berdasarkan hasil pengamatan ektoparasit pada kepiting bakau (Scylla spp.) ditemukan 5 jenis ektoparasit yang berasal dari 2 filum, yaitu filum protozoa dan filum arthropoda. Ektoparasit dari filum protozoa terdiri dari 4 spesies yaitu Zoothamnium sp., Epistylis sp., Carchesium sp., dan Vorticella sp. Sedangkan filum arthropoda terdiri dari 1 spesies yaitu Octolasmis sp.

\section{a. Zoothamnium sp.}

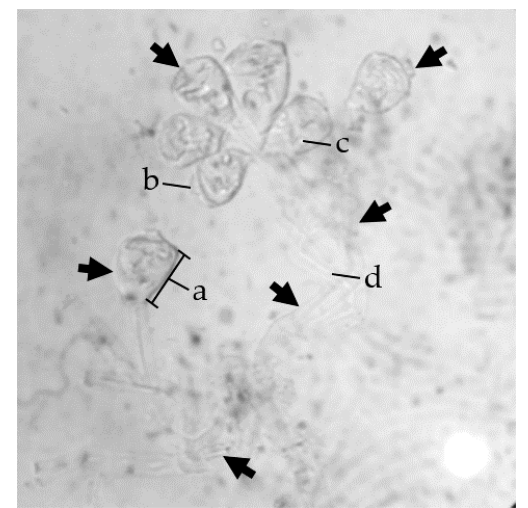

Gambar 4. Zoothamnium sp. dengan pembesaran 100x dan bagian-bagiannya: zooid (a), cilia (b), macronucleus (c) dan stalk (d)
Ektoparasit jenis Zoothamnium sp. mempunyai bentuk tubuh seperti lonceng terbalik, berkontraktil, hidup secara berkoloni dengan banyak cabang di setiap tangkainya, dan berwarna transparan. Zoothamnium sp. memiliki bagian tubuh antara lain adalah macronucleus, cilia, zooid, dan stalk. Hasil pengamatan Zoothamnium sp. dapat dilihat pada Gambar 4.

\section{b. Epistylis sp.}

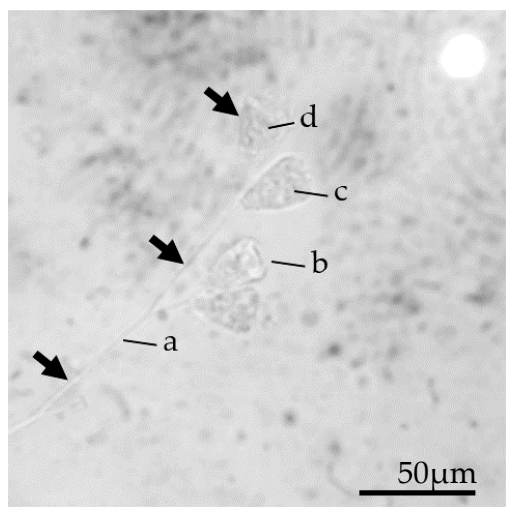

Gambar 5. Epistylis sp. dengan pembesaran 100x dan bagian-bagiannya: stalk (a), cilia (b), vakuola (c) dan nukleus (d)

Ektoparasit jenis Epistylis sp. memiliki ciri-ciri bercabang pada setiap tangkainya namun pada bagian tangkainya tidak mengalami pergerakan (non-contractile). Ektoparasit Epistylis sp. tubuhnya berwarna transparan dan pada umumnya membentuk koloni. Epistylis sp. memiliki bagian tubuh antara lain adalah nukleus, vakuola, cilia, dan stalk. Hasil pengamatan Epistylis sp. dapat dilihat pada Gambar 5.

c. Carchesium sp.

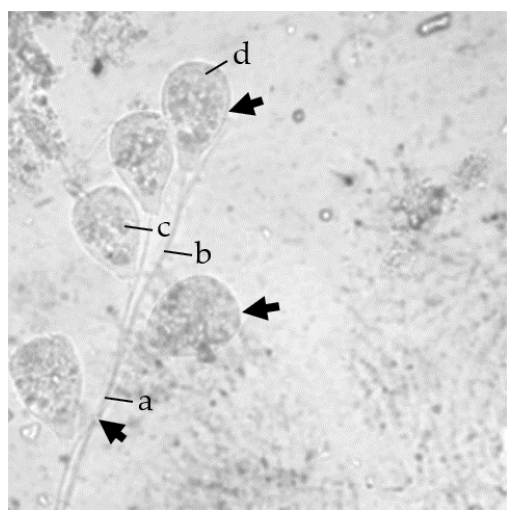

Gambar 6. Carchesium sp. dengan pembesaran 100x dan bagian-bagiannya: stalk (a), myonemes (b), macronucleus (c) dan contractile vacuoles (d) 
Ektoparasit jenis Carchesium sp. memiliki bentuk seperti lonceng terbalik, berwarna transparan dan membentuk sebuah koloni yang dapat menggulung ketika dipicu oleh stimulasi pada beberapa individu. Carchesium sp. memiliki bagian tubuh antara lain adalah contractile vacuoles, macronucleus, myonemes, dan stalk. Hasil pengamatan Carchesium sp. dapat dilihat pada Gambar 6.

\section{d. Vorticella sp.}

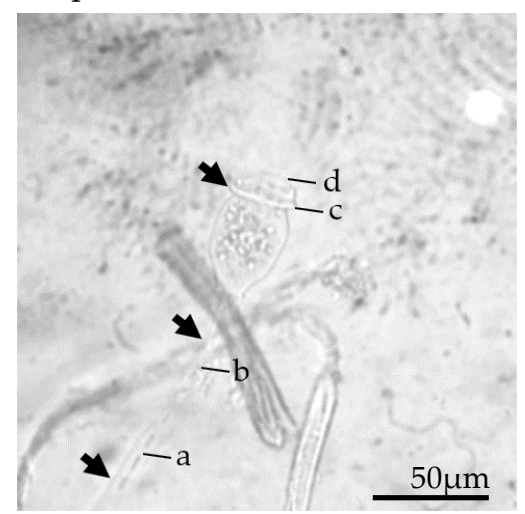

Gambar 7. Vorticella sp. dengan pembesaran 100x dan bagian-bagiannya: stalk (a), myonemes (b), contractile vacuoles (c) dan cilia (d)

Ektoparasit jenis Vorticella sp. memiliki ciri-ciri berbentuk seperti lonceng terbalik dengan warna transparan pada tubuhnya dan mengalami pergerakan pada bagian tangkainya. Ektoparasit ini tidak memiliki percabangan maupun tidak berbentuk koloni (soliter), Vorticella sp. hanya memiliki 1 individu disetiap tangkainya. Vorticella sp. memiliki bagian tubuh antara lain adalah cilia, contractile vacuoles, myonemes dan stalk. Hasil pengamatan Vorticella $\mathrm{sp}$. dapat dilihat pada Gambar 7.

e. Octolasmis sp.

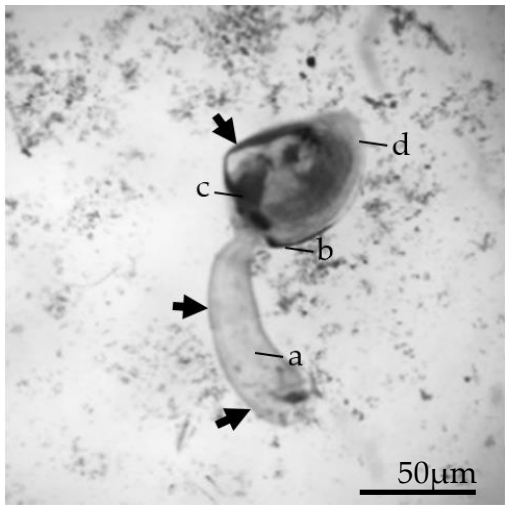

Gambar 8. Octolasmis sp. dengan pembesaran 100x dan bagian-bagiannya: peduncle (a), carina (b), scutum (c) dan tergum (d)
Ektoparasit jenis Octolasmis sp. ditemukan menginfeksi bagian lamela insang kepiting bakau. Octolasmis sp. terlihat berwarna putih pucat, berkontraktil, berbentuk seperti kecambah, dan hidup secara berkoloni pada insang kepiting bakau (Scylla spp.). Octolasmis sp. memiliki bagian tubuh antara lain adalah tergum, scutum, peduncle, dan carina. Hasil pengamatan Octolasmis sp. dapat dilihat pada Gambar 8 .

Hasil pengamatan ektoparasit pada sampel kepiting bakau (Scylla spp.) menunjukkan bahwa ektoparasit ditemukan pada beberapa organ kepiting bakau seperti kaki jalan, kaki renang, karapas, capit, dan insang. Jumlah ektoparasit yang ditemukan pada masing-masing organ secara keseluruhan yaitu capit sebanyak 1348 individu, karapas sebanyak 740 individu, kaki jalan sebanyak 517 individu, kaki renang sebanyak 476 individu, dan insang sebanyak 201 individu dengan total keseluruhan ektoparasit yang menyerang organ kepiting bakau (Scylla spp.) sebanyak 3282 individu.

Tabel 1

Hasil tangkapan kepiting bakau (Scylla spp.)

\begin{tabular}{|c|c|c|c|c|c|c|}
\hline \multirow[t]{2}{*}{ Parasit } & \multicolumn{5}{|c|}{ Predileksi } & \multirow[t]{2}{*}{$\begin{array}{l}\text { Total } \\
\text { (ind) }\end{array}$} \\
\hline & KJ & KR & $\mathrm{K}^{*}$ & $\mathrm{C}$ & I & \\
\hline $\mathrm{Z}$ & 347 & 232 & 563 & 879 & 0 & 2021 \\
\hline $\mathrm{E}$ & 166 & 230 & 125 & 434 & 0 & 955 \\
\hline $\mathrm{C}$ & 0 & 0 & 0 & 7 & 0 & 7 \\
\hline V & 4 & 14 & 52 & 28 & 0 & 98 \\
\hline $\mathrm{O}$ & 0 & 0 & 0 & 0 & 201 & 201 \\
\hline $\begin{array}{l}\text { Total } \\
\text { (ind) }\end{array}$ & 517 & 476 & 740 & 1348 & 201 & 3282 \\
\hline
\end{tabular}

Keterangan:

$\begin{array}{llll}\mathrm{Z} & \text { : Zoothamnium sp. } & \mathrm{KJ} & \text { : Kaki Jalan } \\ \mathrm{E} & \text { : Epistylis sp. } & \mathrm{KR} & \text { : Kaki Renang } \\ \mathrm{C} & \text { : Carchesium sp. } & \mathrm{K}^{*} & \text { : Karapas } \\ \mathrm{V} & \text { : Vorticella sp. } & \mathrm{C} & \text { : Capit } \\ \mathrm{O} & \text { : Octolasmis sp. } & \mathrm{I} & \text { : Insang }\end{array}$

\subsubsection{Pengukuran parameter kualitas air}

Pengukuran parameter kualitas air pada lokasi penelitian meliputi suhu, DO (Dissolved Oxygen), $\mathrm{pH}$, dan salinitas. Hasil rata-rata pengukuran di seluruh stasiun yaitu suhu $29,9{ }^{\circ} \mathrm{C}$; DO $6,6 \mathrm{mg} / \mathrm{L}$; pH 7,39; dan salinitas 20\%.

\section{Pembahasan}

4.1 Jenis ektoparasit dan predileksi yang menginfeksi kepiting bakau (Scylla spp.) di TAHURA Ngurah Rai, Bali 
Berdasarkan hasil jenis-jenis ektoparasit yang menginfeksi kepiting bakau (Scylla spp.) di TAHURA Ngurah Rai, Bali, ditemukan 5 spesies ektoparasit yang berasal dari filum protozoa dan arthropoda. Spesies ektoparasit dari filum protozoa meliputi Zoothamnium sp., Epistylis sp., Vorticella sp., dan Carchesium sp, sedangkan spesies ektoparasit dari filum arthropoda yaitu Octolasmis sp. hal ini dikarenakan kelima jenis ektoparasit tersebut merupakan jenis-jenis ektoparasit yang sering ditemukan menginfeksi pada kepiting bakau. Hal ini sesuai dengan penelitian Fitriyanti (2016) yang menyebutkan bahwa ektoparasit yang sering ditemukan pada kepiting bakau yaitu Octolasmis sp., Vorticella sp.,Carchesium sp., Epistylis sp. dan Zoothamnium sp.

Ektoparasit yang paling banyak ditemukan adalah Zoothamnium sp. dengan jumlah ektoparasit sebanyak 2021 individu. Ektoparasit tersebut ditemukan menginfeksi beberapa organ kepiting bakau seperti pada kaki jalan, kaki renang, karapas, dan capit dengan jumlah koloni yang beragam pada setiap organ. Infeksi ektoparasit yang melimpah disebabkan karena Zoothamnium sp. dan Epistylis sp. merupakan ektoparasit yang hidup secara berkoloni (Schuwerack et al., 2001), sehingga proses perkembangbiakan dengan berkoloni akan lebih cepat dibandingkan dengan Vorticella sp. yang hidup secara soliter (Li et al., 2008). Berdasarkan hasil pengukuran kualitas air di TAHURA Ngurah Rai, Bali masih dikatakan layak untuk proses hidup kepiting bakau karena masih dalam kisaran normal, akan tetapi beberapa kondisi perairan tersebut mendukung pertumbuhan dan kehidupan parasit, hal ini didukung dengan penelitian Fitriyanti (2016) yang menyebutkan bahwa Zoothamnium sp. ditemukan pada kisaran suhu $30-32{ }^{\circ} \mathrm{C}$, DO 2,8-5,4 mg/L, pH 7,9-8,7, dan salinitas $19-28 \%$.

Epistylis sp. ditemukan menginfeksi pada organ kaki jalan, kaki renang, karapas, dan capit dengan jumlah total ektoparasit sebanyak 955 individu. Banyaknya spesies Epistylis sp. dikarenakan menurut Nicolau et al. (2005) ektoparasit jenis Epistylis sp. banyak ditemukan pada daerah yang bersubstrat. Beberapa faktor lainnya seperti konsentrasi DO yang rendah dapat meningkatkan pertumbuhan Epistylis sp. Ma dan Overstreet (2006) menambahkan bahwa Epistylis sp. dapat bereproduksi secara optimum pada perairan dengan suhu $10-25{ }^{\circ} \mathrm{C}$, $\mathrm{pH}$ 6,5-7 dan salinitas 15$31 \%$. Namun pada penelitian Fitriyanti (2016)
Epistylis sp. juga ditemukan melimpah pada kisaran suhu 30-32 ${ }^{\circ} \mathrm{C}$, DO 2,8-5,4 mg/L, pH 7,98,7, dan salinitas $19-28 \%$.

Vorticella sp. memiliki bentuk hampir menyerupai Epistylis sp. dan Carchesium sp., namun Epistylis sp. dan Carchesium sp. hidup berkoloni sedangkan Vorticella sp. bersifat soliter. Pergerakan ektoparasit ini menyerupai Carchesium sp. dimana tangkai pada Vorticella sp. dapat memendek dan menggulung. Adanya pergerakan tersebut maka memungkinkan Vorticella sp. untuk berpindah tempat. Hal ini diperkuat oleh pernyataan Aziz et al. (2013) bahwa tangkai pada Vorticella sp. dapat memendek dan menggulung ketika distimulasi dengan pergerakan. Menurut Fitriyanti (2016) bahwa Vorticella sp. ditemukan pada kepiting bakau dengan parameter kualitas air kisaran suhu 30-32 ${ }^{\circ} \mathrm{C}$, DO 2,8-5,4 mg/L, pH 7,98,7 , dan salinitas $19-28 \%$.

Carchesium sp. pada penelitian ini ditemukan dengan jumlah sebesar 7 individu/ekor dan ditemukan menginfeksi kepiting bakau pada organ capit. Carchesium sp. yang ditemukan berbentuk seperti bunga lonceng, memiliki silia dan terlihat berkoloni dimana satu koloni memiliki lebih dari 3 individu. Hal ini diperkuat oleh Kabata (1985) bahwa Carchesium sp. merupakan ektoparasit yang dapat hidup berkoloni. Berdasarkan hasil pengamatan, koloni dari Carchesium sp. dapat bergerak dan menggulung ketika terjadi stimulasi pada beberapa induvidu dalam satu koloni. Gerakan yang terjadi pada salah satu cabang dari Carchesium sp. dapat memicu cabang lain dari tangkai utama untuk ikut bergerak. Hal ini sesuai dengan pernyataan Aziz et al. (2013) bahwa stimulasi yang terjadi pada beberapa individu dalam satu koloni akan memicu terjadinya reaksi berantai sehingga keseluruhan koloni akan menggulung membentuk suatu bulatan. Setiyaningsih et al. (2014) menambahkan dalam penelitiannya bahwa ektoparasit tersebut juga mampu bertahan hidup pada kualitas air dengan kisaran suhu $31-32{ }^{\circ} \mathrm{C}$, DO 2,7-3,0 mg/L, $\mathrm{pH}$ 8,2-8,5, dan salinitas 23-25\%.

Octolasmis sp. yang ditemukan pada organ insang dengan jumlah yang beragam disetiap individu kepiting bakau (Scylla spp.) yang terinfeksi. Menurut Irvansyah et al. (2012) bahwa Octolasmis sp. hanya ditemukan pada bagian organ insang dikarenakan siklus hidup dari Octolasmis sp. yang membutuhkan kebutuhan nutrisi yang lebih untuk hidup dan berkembangnya. Insang 
merupakan organ yang paling sering dialiri darah, terdapat pembuluh-pembuluh darah dan pelindungnya berupa jaringan epitel selapis yang tipis sehingga ektoparasit tersebut sangat mudah diserang. Nurcahyo dan Katsuri (2014) menambahkan bahwa Octolasmis sp. dalam jumlah yang besar dapat menyebabkan kondisi inang menjadi lemah dan menurunkan nafsu makan sehingga mengakibatkan penurunan berat badan yang berdampak merugikan para pembudidaya. Setiyaningsih et al. (2014) menambahkan dalam penelitiannya bahwa Octolasmis sp. ditemukan pada kualitas air dengan kisaran suhu $31-32{ }^{\circ} \mathrm{C}$, DO 2,7-3,0 mg/L, pH 8,2-8,5, dan salinitas 23-25\%.

Secara umum organ yang paling rentan terserang ektoparasit adalah pada insang kepiting bakau. Hal ini disebabkan insang adalah organ pernapasan yang langsung berhubungan dengan lingkungan yang ada di sekitarnya. Hal ini sesuai dengan pendapat Yuliartati (2011) bahwa letak insang, struktur dan mekanisme kontak dengan lingkungan menjadikan organ insang sangat rentan terhadap perubahan kondisi lingkungan yang ada di sekitar. Organ lainnya seperti kaki jalan, kaki renang, capit, dan karapas ditemukan terinfeksi ektoparasit dengan jumlah infeksi yang beragam. Hal ini tidak sesuai dengan pernyataan Irvansyah et al. (2012) bahwa kaki jalan, kaki renang, capit, dan karapas merupakan organ yang paling sedikit diserang ektoparasit karena kaki jalan dan kaki renang sering bersentuhan langsung dengan substrat keras dan memiliki pelindung sehingga sulit diserang parasit, begitu pula dengan organ capit dan karapas.

\subsection{Pengukuran parameter kualitas air}

Hasil pengukuran beberapa parameter kualitas air yang diperkirakan mempengaruhi jumlah tangkapan kepiting bakau dan tingkat infeksi ektoparasit pada kepiting bakau di Taman Hutan Raya Ngurah Rai, Bali meliputi suhu, DO, pH, dan salinitas. Hasil pengukuran suhu pada masingmasing stasiun didapatkan hasil suhu berkisar antara 28,1-31,4 ${ }^{\circ} \mathrm{C}$. Hal ini sesuai dengan pernyataan Shelley dan Lovatelli (2011) yang menyebutkan bahwa suhu optimal untuk kehidupan kepiting bakau kisaran $25-35{ }^{\circ} \mathrm{C}$. Hasil pengukuran DO pada masing-masing stasiun didapatkan hasil DO berkisar antara 4,7-7,7 mg/L. Hal ini sesuai dengan pernyataan Shelley dan Lovatelli (2011) yang menyatakan bahwa DO yang baik untuk kehidupan kepiting bakau adalah $>5$
mg/L. Hasil pengukuran salinitas pada masingmasing stasiun didapatkan hasil salinitas berkisar antara $7-28 \%$. Hal ini sesuai dengan pernyataan Shelley dan Lovatelli (2011) yang menyatakan bahwa salinitas yang baik untuk kehidupan kepiting bakau adalah $10-25 \%$. Nilai pengukuran $\mathrm{pH}$ pada masing-masing stasiun didapatkan hasil pH berkisar antara 7,23-7,60. Hal ini sesuai dengan pernyataan Shelley dan Lovatelli (2011) yang menyatakan bahwa $\mathrm{pH}$ yang baik untuk kehidupan kepiting bakau adalah 7,5-9,0.

\section{Simpulan}

Jenis ektoparasit yang telah ditemukan menginfeksi kepiting bakau (Scylla spp.) di Taman Hutan Raya (TAHURA) Ngurah Rai, Bali adalah Octolasmis sp., Vorticella sp., Carchesium sp., Epistylis sp., dan Zoothamnium sp. Kondisi kualitas air di Tahura Ngurah Rai, Bali relatif stabil dan cukup untuk kehidupan kepiting bakau (Scylla spp.) dengan data rata-rata pengukuran kualitas air yaitu suhu $29,9^{\circ} \mathrm{C}$; DO 6,6 mg/L; pH 7,39; dan salinitas $20 \%$.

\section{Daftar Pustaka}

Aziz., H. Iromo., \& Darto. (2013). Identifikasi Ektoparasit pada Udang Windu (Penaeus Monodon Fabricus) di Tambak Tradisional Kota Tarakan. Artikel Ilmiah. Tarakan, Indonesia: Fakultas Perikanan dan Ilmu Kelautan, Universitas Borneo Tarakan.

FAO \& NACA. (2001). Asia Diagnostic Guide to Aquatic Animal Diseases. Bangkok, Thailand: Food and Agriculture Organization dan Network of Aquaculture Centers in Asia-Pacific.

Fitriyanti, S. (2016). Keanekaragaman Ektoparasit Kepiting Bakau (Scylla serrata) Dari Perairan Tambak Desa Wonosari Kabupaten Kendal. Skripsi. Semarang, Indonesia: Fakultas Perikanan dan Kelautan, Universitas Diponegoro.

Idrus, Mahasri, G., \& Subekti, S. (2016). Prevalensi dan Intensitas Ektoparasit pada Kepiting Bakau (Scylla serrata) Hasil Tangkapan di Pesisir Kenjeran Surabaya. J. of Marine and Coastal Scince, 5(1), 49-57.

Irvansyah, Y.M., N. Abdulgani, \& G. Mahasri. (2012). Identifikasi dan Intensitas Ektoparasit pada Kepiting Bakau (Scylla serrata) Stadia Kepiting Muda di Pertambakan Kepiting, Kecamatan Sedati, Kabupaten Sidoarjo. Jurnal Sains dan Seni. 1, 5-9.

Kabata, Z. (1985). Parasites and diseases of fish cultured in the tropis. British Columbia, Canada: Pacific Biological Station. 
KKP. (2014). Perikanan Budidaya Indonesia, Direktorat Jenderal Perikanan Budidaya. Indonesia: Kementerian Kelautan dan Perikanan.

Li YY, Xia XA, Wu QY, Liu WH, \& Lin YS. (2008). Infection with Hematodinium sp. in mud crabs Scylla serrata cultured in low salinity water in southern China. Diseases of Aquatic Organisms, 82, 145-150.

Lightner, D.V., 1983. Diseases of cultured penaeid shrimp. In: McVey, J.P. (Editor), CRC Handbook of Mariculture, (2nd edn.), Vol. 1, Crustacean Aquaculture. CRC Press, Boca Raton, FL., 289-320.

Ma, H. \& R. M. Overstreet. (2006). Two New Species of Epistylis (Ciliophora: Peritrichida) on the Blue Crab (Callinectes sapidus) in the Gulf of Mexico. Department of Coastal Sciences, The University of Southern Mississippi. Ocean Springs, Eukaryot. Microbiol, 53(2), 85-95.

McDermott, J.J., J.D. Williams \& C. B. Boyko. (2010). The Unwanted Guests of Hermits: a Global Review of the Diversity and Natural History of Hermit Crab Parasites. Journal of Experimental Marine Biology and Ecology, 394, 2-44.

Moller, H. \& K. Anders. (1986). Diseases and Parasites of Marine Fishes. Australia: Libraries Australia.

Nicolau, A., Martins, M.J., Mota, M. \& Lima, N. (2005). Effect of Copper in the Protistan Community of Activated Sludge. Chemosphere, 58, 605-614.

Nurcahyo, E. \& Katsuri. (2014). Aplikasi system Resirkulasi Sederhana Dalam Mempercepat Pemijahan Induk Kepiting Bakau Scylla Olivacea Herbst. Sulawesi, Indonesia: Balai Budidaya Air Payau Takalar.

Pratiwi, R. \& E. Widyastuti. (2013). Kepiting Suku Portunidae (Decapoda: Brachyura) dari perairan Indonesia, Bagian I, Genus: Portunus spp., Thalamita spp., Charybdis spp. dan Scylla spp. Indonesia: Pusat Penelitian Oseanografi LIPI.

Rancak, G.N., (2014). Studi pencemaran limbah domestik di Kawasan Pantai Kenjeran Surabaya. Skripsi. Surabaya, Indonesia: Fakultas Teknologi Kelautan, Institut Teknologi Sepuluh November.
Schuwerack, P. M. M., J.W, Lewis., \& P. W. Jones. (2001). Pathological and Physiological Changes in the South African Freshwater Crab Potamonautes warreni Calman Induced by Microbial Gill Infestations. Invertebrate Pathology, 77, 269 -279.

Setiyaningsih, L., Sarjito, \& Haditomo, A. H. C. (2014). Identifikasi Ektoparasit pada Kepiting Bakau (Scylla serrata) yang dibudidayakan ditambak Pesisir Pemalang. Journal of Aquaculture Management and Technology, 3(3), 8-16.

Shelley, C. \& A. Lovatelli. (2011). Mud crab aquaculture a practical manual. FAO Fisheries and Aquaculture Technical Paper, 567.

Sianipar, A.S., Sitorus, H., \& Harahap, Z.A. (2017). Pengaruh Jenis Umpan Terhadap Hasil Tangkapan Kepiting Bakau (Scylla Serrata) Di Kawasan Hutan Mangrove Kelurahan Belawan Sicanang Provinsi Sumatera Utara. Jurnal AquacoastmarineI, 5, 3.

Ulfa, M. (2016). Keterkaitan struktur komunitas makrozooobentos dengan kualitas air dan substrat di ekosistem mangrove Taman Hutan Raya (TAHURA) Ngurah Rai, Desa Pamogan, Denpasar, Bali. Skripsi. Badung, Indonesia: Fakultas Kelautan dan Perikanan, Universitas Udayana.

Wijaya, N. I. (2011). Pengelolaan Zona Pemanfaatan Ekosistem Mangrove Melalui Optimasi Pemanfaatan Sumberdaya Kepiting Bakau (Scylla serrata) di Taman Nasional Kutai Provensi Kalimantan Timur. Skripsi. Bogor, Indonesia: Sekolah pasca sarana institute pertanian bogor.

Yuliartati, E. (2011). Tingkat Serangan Ektoparasit pada Ikan Patin (Pangasius djambal) pada Beberapa Budidaya di Kota Makassar. Skripsi. Makassar, Indonesia: Program Studi Budidaya Perairan, Jurusan Perikanan Fakultas Ilmu Kelautan dan Perikanan, Universitas Hasanuddin.

Yusuf. (2012). Identifikasi Dan Intensitas Ektoparasit Pada Kepiting Bakau (Scylla serrata) Stadia Kepiting Muda di Pertambakan Kepiting, Kecamatan Sedati, Kabupaten Sidoarjo. Jurnal Sains Dan Seni ITS, 1(1), E 5-9. 